\title{
BIOCHEMICAL PROFILE OF BACTERISED CALLI AND EMBRYOGENIC CALLI OF OIL PALM (Elaeis guineensis Jacq.)
}

SHEY-LI LIM*; SREERAMANAN SUBRAMANIAM*; ISHAK ZAMZURI** and HAMZAH GHAZALI AMIR*

\begin{abstract}
Recent approaches have been made with regard to successful association of in vitro oil palm materials and diazotrophs. But, no biochemical study was revealed to explain possible relationship between the diazotroph and in vitro oil palm plant proliferation processes. In this study, calli and embryogenic calli of oil palm (Elaeis guineensis Jacq.) were treated with different inoculums of Herbaspirillum seropedicae strain Z78 (ATCC 35893) namely, sonicated cells and pellet cells. Treated oil palm tissues were observed for total amino acids, proteins, phenolics and sugar levels which were extracted and quantified every 10 days throughout 60 days of culturing. Results reveal a reduction of total sugar levels, increment of phenolics, amino acids and protein contents of bacterised calli with Z78 pellet cells which can explain rapid progression of embryogenic development. High content of phenolic compounds, sugar levels with the reduction of amino acids and proteins in bacterised embryogenic calli with Z78 sonicated cells would elucidate accelerated embryo regeneration and maturation. These results provide a novel explanation for biochemical profiles of bacterised oil palm calli and embryogenic calli. With the understanding of biochemical patterns, this can act as a guide for further in-depth study on in vitro plant cells-microbe interactions.
\end{abstract}

Keywords: bacterised in vitro oil palm culture, diazotrophs, Herbaspirillum seropedicae (Z78), calli, embryogenic calli.

Date received: 1 June 2017; Sent for revision: 22 June 2017; Received in final form: 3 April 2018; Accepted: 5 July 2018.

\section{INTRODUCTION}

Diazotrophic bacteria have enormous commercialisation potential in promoting cell growth of plant tissue culture materials (Nowak, 1998). In addition, diazotrophs also have the ability to form associative interactions with in vitro plant cultures. Studies have reported that diazotrophic bacteria have great potential to form symbiotic association with a wide range of monocotyledon plants such as rice, sugar-cane and oil palm (Keyeo et al., 2011; Taule et al., 2012; Lim et al., 2018). Herbaspirillum seropedicae strain Z78 is a diazotrophic beta-proteobacterium that can fix atmospheric

School of Biological Sciences, Universiti Sains Malaysia, 11800 Minden, Pulau Pinang, Malaysia.

E-mail: amirhg@usm.my

** Malaysian Palm Oil Board, 6 Persiaran Institusi, Bandar Baru Bangi, 43000 Kajang, Selangor, Malaysia. nitrogen and produce phytohormone particularly indole-3-acetic acid (IAA). In our previous study, Z78 has been proven for its ability to promote proliferation of callus and embyrogenic callus of oil palm (Lim et al., 2016a, b). As a consequence of the interactions, diazotroph could probably initiate cell proliferation and differentiation of oil palm calli and embryogenic calli in response to nitrogen supplied via nitrogen $\left(\mathrm{N}_{2}\right)$ fixation process and hormonal stimuli such as IAA (Lim et al., 2016b). Due to the potential application of diazotrophs with in vitro plant, various morphological analyses have been done to understand the interactions of bacteria and in vitro plant culture materials such as carrot, strawberry, rice, cormlet and oil palm (Varga et al., 1994; Preininger et al., 1997; Oliveira et al., 2002; Parray et al., 2015; Lim et al., 2016a, b). In spite of the potentials and current understanding of diazotrophs and in vitro plant interactions, research data could 
not fully explain the mechanism of interactions at biochemical level. Thus, by improving biochemical understanding, it would provide a better insight into possible changes of the bacterised oil palm tissue that might occur during cell differentiation and proliferation processes and also the potential application of diazotrophic bacteria in plant tissue culture process.

In plant tissue culture, comprehensions of organic compounds production for instance primary and secondary metabolites are the prerequisite for plant cell growth. Biochemical studies are essential in order to have a better understanding of the morphological and physiological features of plant cells which may be due to the artificial symbiotic association. Amino acid is important in plant development pathway and several studies had reported that drastic increment and reduction of amino acids production occurred during different stages of somatic embryogenesis process (Sen et al., 2002; Booz et al., 2009; Kumar and Kumari, 2011; Gomes et al., 2014). Generally, proteins are involved in cell expansion regulation and establishment of biophysical characteristics which are required for plant cell morphogenesis (Jiménez, 2001). The histodifferentiation of somatic embryos was also associated with the mobilisation and synthesis of proteins (Cangahuala-Inocente et al., 2009). In addition, phenolic is an important group of secondary metabolites, it may act as modulator of plant development by regulating IAA catabolism which can rapidly enhance cell division and elongation thus further synthesise cell wall and other cell components (Arnaldos et al., 2001). While sugar is the main energy provider in plant tissue culture during cell growth as the carbon sources, it is also involved in many metabolic and signalling pathways for plants (Martin et al., 2000; Bolouri-Moghaddam and Van den Ende, 2012). The importance of amino acids, proteins, phenolics and sugars as a cell metabolism regulator, has significant impacts on plant-microbes interaction towards colonisation via bacterial chemotaxis, motility and plant developmental processes (Steenhoudt and Vanderleyden, 2000; Drogue et al., 2012).

As a consequence, it is believed that the application of diazotroph Z78 can orchestrate and affect the organic compounds accumulation at the oil palm cell development stages and thus accelerate the in vitro oil palm cell differentiation and proliferation processes. Despite various studies conducted, the mechanisms that regulate the growth stages of in vitro oil palm cultures in association with bacterial cells still remain unclear. It is believed that biochemical studies during somatic embryogenesis under symbiotic association can provide important information in understanding the relationship between the reserved compounds and the effects of bacterial cells towards plant tissue cell growth. Given the importance and need to understand the biochemical profile of bacterised in vitro oil palm cultures, thus, this experiment has been conducted to comprehend the biochemical profiles such as total amino acids, total protein contents, total phenolic compounds and total sugar contents accumulation of treated in vitro oil palm cultures. Also, to determine the effect of the bacterisation process towards progression of calli and embryogenic calli development. Any changes on the biochemical profile of the oil palm calli and embryogenic calli associated with bacterial cells may further explain the functions of diazotroph in the plant development stages.

\section{MATERIALS AND METHODS}

\section{Plant Materials}

Calli and embryogenic calli of Elaeis guineensis clone P614D (Dura) were supplied by the Advanced Biotechnology and Breeding Centre (ABBC), Malaysian Palm Oil Board (MPOB). Calli with a total weight of $0.08 \pm 0.01 \mathrm{~g}$ per sample and embryogenic calli with diameter of $0.5 \pm 0.1 \mathrm{~cm}$ per sample were cultured on modified Murashige and Skoog (1962) MS medium, containing $1.65 \mathrm{~g}$ litre ${ }^{-1}$ of $\mathrm{NH}_{4} \mathrm{NO}_{3}$ and $1.9 \mathrm{~g} \mathrm{litre}^{-1}$ of $\mathrm{KNO}_{3}$ in $100 \%$ (w/v) nitrogen sources (N), $2.0 \mathrm{mg}$ litre $^{-1}$ and $0.2 \mathrm{mg} \mathrm{litre}^{-1} 2,4-\mathrm{D}$ as $100 \%(\mathrm{w} / \mathrm{v})$ supplement of plant growth regulator for calli and embryogenic calli in each culture tube $(10.0 \mathrm{ml}$ in a $10 \mathrm{~cm} \times 2.5 \mathrm{~cm})$. The calli and embryogenic calli were treated with the following treatments namely: i) $100 \%(\mathrm{w} / \mathrm{v}) \mathrm{N}+100 \%(\mathrm{w} / \mathrm{v})$ $2,4-\mathrm{D}$; ii) $25 \%(\mathrm{w} / \mathrm{v}) \mathrm{N}+10 \%$ (w/v) $2,4-\mathrm{D}$; iii) $25 \%$ $(\mathrm{w} / \mathrm{v}) \mathrm{N}+10 \%(\mathrm{w} / \mathrm{v}) 2,4-\mathrm{D}+\mathrm{Z} 78$ sonicated cells; and iv) $25 \%(\mathrm{w} / \mathrm{v}) \mathrm{N}+10 \%(\mathrm{w} / \mathrm{v}) 2,4-\mathrm{D}+\mathrm{Z} 78$ pellet cells. Treated in vitro plant cultures were monitored for their morphological differentiation, increment of biomass and alteration of the biochemical profiles (total sugar contents, total phenolic compounds, total amino acid levels and total protein contents) in every 10 days interval and for a total of 60 days of cultivation period.

\section{Bacterial Preparation}

Herbaspirillum seropedicae strain Z78 (ATCC 35893) was cultured in N-limited broth (50.0 ml per flask) (Okon et al., 1977). The culture was incubated for $24 \mathrm{hr}$ at room temperature and shaken at $180 \mathrm{rpm}$, until it reached the optimal optical density of $\mathrm{OD}_{600 \mathrm{~nm}}$ with colony-forming unit (cfu) approximately fixed at $10^{7}$ to $10^{8} \mathrm{cfu} \mathrm{ml}^{-1}$. A total of two different bacterial inoculums namely: Z78 pellet cells and Z78 sonicated cells were prepared for this experiment. For pellet cells inoculum preparation, a total of $50 \mathrm{ml}$ bacterial broth culture was transferred into a falcon tube and centrifuged at $10000 \mathrm{rpm}$ for $10 \mathrm{~min}$. The pellet 
cells were washed and resuspended twice in $50 \mathrm{ml}$ distilled water before the inoculation. For sonicated cells inoculum preparation, washed pellet cells suspended with sterile distilled water were put into a sonicator (JAC Ultrasonic 2010p, Korea) and fixed with $40 \mathrm{KHz}$ working frequency, $300 \mathrm{~W}$ ultrasonic power and high ultrasonic output variableness. The sonication time was fixed as $30 \mathrm{~min}$. Samples were then centrifuged at $10000 \mathrm{rpm}$ for $10 \mathrm{~min}$ and the collected supernatants were ready for inoculation.

\section{Viable Cell Count and Biomass Increment}

Viable cell count of $H$. seropedicae (Z78) was observed in every 20 days interval using Miles and Misra method (1938). The well-developed samples of treated calli and embryogenic calli were removed from the culture tubes and crushed using glass rod in a bijoux bottle containing $10 \mathrm{ml}$ saline. A total of $1 \mathrm{ml}$ of crushed sample was pipetted into $9 \mathrm{ml}$ of saline water in 10-fold series dilution from $10^{-1}$ to $10^{-9}$ and $30 \mu \mathrm{l}$ from each dilution was plated onto Congo red medium. The plates were incubated up to $48 \mathrm{hr}$ and colonies were counted for viable cell count analysis. Treated calli and embryogenic calli were measured for fresh weight using electronic weighing machine (Denver Instrument AA-200DS) throughout the experiment.

\section{Histological Studies}

Both treated calli and embryogenic calli were fixed using McDowell's fixative (McDowell and Trump, 1976), containing $0.1 \mathrm{M}$ phosphate buffer $\mathrm{pH} 7.2$ at $4^{\circ} \mathrm{C}$. The samples were washed in the same buffer for $10 \min (\mathrm{x} 3)$, then postfixed in $1 \%(\mathrm{w} / \mathrm{v})$ osmium tetraoxide (prepared in $0.1 \mathrm{M}$ phosphate buffer $\mathrm{pH}$ 7.2) for $2 \mathrm{hr}$, washed and dipped into distilled water twice. The samples underwent a series of dehydration processes: $50 \%(\mathrm{v} / \mathrm{v})$ ethanol for $15 \mathrm{~min}$; 75\% (v/v) ethanol for $15 \mathrm{~min}$; $90 \%$ (v/v) ethanol for 15 min (two times) and 100\% (v/v) ethanol for 20 min (x 2) (Glauert, 1980; Dyksta, 1992). Dehydrated samples were immersed in acetone: Spurr's resin mix (1:1) overnight in a rotator. On the next day, samples were infiltrated in a new change of Spurr's mix for the following three days before full moulding by using the embed cube at $60^{\circ} \mathrm{C}$ for $24 \mathrm{hr}$ (Spurr, 1969). Specimens were sectioned using ultramicrotomy and stained with toluidine blue (Guedes et al., 2013). The sections were mounted on slides and examined under Olympus light microscope.

\section{Determination of Total Amino Acid Contents}

Total amino acid contents of treated calli and embryogenic calli were assayed according to Lee and Takashi (1966). A total of $100 \mathrm{mg}$ of homogenised tissues of treated calli and embryogenic calli were incubated overnight in $70 \%(\mathrm{v} / \mathrm{v})$ ethanol followed by washing with double distilled water. The samples were then treated with $1.5 \mathrm{ml}$ of $55 \%(\mathrm{v} / \mathrm{v})$ glycerol and $0.5 \mathrm{ml}$ ninhydrin solution, boiled for $20 \mathrm{~min}$ and cooled down. The final volume was made up to $6 \mathrm{ml}$ with double distilled water, and optical density was measured at $570 \mathrm{~nm}$. The amino acid concentrations were determined using proline standard curve.

\section{Determination of Total Protein Contents}

The Bradford reagent was used for protein content analysis (Bradford, 1976). A total of $0.1 \mathrm{~g}$ of Coomassive Blue G250 was dissolved in $50 \mathrm{ml}$ 95\% (v/v) ethanol, mixed with $100 \mathrm{ml}$ of $85 \%$ (v/v) phosphoric acid and finally made up to 1 litre with distilled water. The reagent was filtered through Whatman filter paper (No. 1) before use for the analysis. Tissues of calli and embryogenic calli were homogenised using liquid nitrogen and placed into microcentrifuge tubes for subsequent process. A total of $1.0 \mathrm{ml} 0.1 \mathrm{M}$ potassium phosphate buffer $\mathrm{pH}$ 7 was added and centrifuged at $5000 \mathrm{rpm}$ for $10 \mathrm{~min}$. The samples were mixed with $0.5 \mathrm{ml}$ trichloroacetic acid (TCA) and centrifuged at $5000 \mathrm{rpm}, 10 \mathrm{~min}$. The supernatant was discarded and the pellet cell was kept. The pellet cell was resuspended in 0.1 $\mathrm{N} \mathrm{NaOH}$ and $0.5 \mathrm{M}$ Bradford reagent. The optical density of each sample was determined at $595 \mathrm{~nm}$. The protein content of each sample was calculated based on the protein assay standard curve (mg BSA per $\mathrm{ml}$ protein).

\section{Determination of Total Phenolic Compounds}

The total phenolic compounds of treated plant samples were determined based on modified Folin-Ciocalteu colorimetric method (Singleton and Rossi, 1965). Calli and embryogenic calli were homogenised using liquid nitrogen, suspended in 1 $\mathrm{ml}$ of $80 \%(\mathrm{v} / \mathrm{v})$ aqueous ethanol and centrifuged at $880 \mathrm{x} \mathrm{g}$ for $20 \mathrm{~min}$. The supernatant was collected $(100 \mu \mathrm{l})$ and mixed with $1 \mathrm{ml}$ of $5 \%(\mathrm{w} / \mathrm{v}) \mathrm{Na}_{2} \mathrm{CO}_{3}$ and $0.5 \mathrm{ml}$ of $50 \%(\mathrm{v} / \mathrm{v})$ Folin-Ciocalteau reagent. The absorbance at $760 \mathrm{~nm}$ was measured using a spectrophotometer. The total phenolic compounds were calculated based on gallic acid standard curve and expressed in milligram of gallic acid equivalents per milligram of calli and embryogenic calli fresh weight.

\section{Determination of Total Sugar Contents}

The total sugar content was determined using phenol-sulphuric acid method (Dubois et al., 1956). A total of $100 \mathrm{mg}$ homogenised calli and embryogenic calli in each treatment were extracted with $80 \%$ $(\mathrm{v} / \mathrm{v})$ aqueous ethanol and centrifuged at $880 \mathrm{x} \mathrm{g}$ for 
$20 \mathrm{~min}$. A total of $100 \mu \mathrm{l}$ supernatant was mixed with $1 \mathrm{ml}$ of $5 \%(\mathrm{v} / \mathrm{v})$ phenol and $0.5 \mathrm{ml}$ of concentrated sulphuric acid. The absorbance was measured at $490 \mathrm{~nm}$ and the total soluble sugar content was calculated based on glucose standard curve and expressed as milligram glucose per milligram of calli and embryogenic calli fresh weight.

\section{Statistical Analysis}

The experiment was performed in a completely randomised design (CRD) with 30 replicates per treatment and repeated twice. The collected data were analysed using analysis of variance and the differences among the treatments were compared based on Tukey's HSD (T1) at P $<0.05$ using SPSS (Version 20, SPSS).

\section{RESULTS AND DISCUSSION}

\section{Morpho-histological, Biomass Increment and Viable Cell Count}

In our study, non-bacterised calli treated with $100 \%(\mathrm{w} / \mathrm{v}) \mathrm{N}+100 \%(\mathrm{w} / \mathrm{v}) 2$, 4-D (T1) and bacterised calli with Z78 pellet cells (T4) showed morphogenetic responses, by inducing cell differentiation of friable embryogenic calli segments. In general, the production of friable embryogenic calli from nodular calli in oil palm, will take up to two to four months whereas embryogenic calli would form after three to six months of culture from callus (Te-chato and Hilae, 2007). Hence, it is believed that Z78 is a potential diazotroph that can enhance cell differentiation in comparison with normal cultivation practice. In addition, isodiametric cells and starch accumulations were observed in the calli treated with $100 \%(\mathrm{w} / \mathrm{v}) \mathrm{N}+100 \%(\mathrm{w} / \mathrm{v})$ 2, 4-D (T1) Z78 pellet cells (T4) and bacterised embryogenic calli treated with Z78 sonicated cells (T3) (Figures $1 a, 1 b$ and $1 d$ ). According to Balzon et al. (2013), the intense cell division can only be detected in the internal part of the calli and presented as a cell development process. Also, earlier reports have shown that small and isodiametric cells exhibited dense cytoplasm and starch accumulation indicating that cell development was in progress towards embryogenesis (Padua et al., 2013; de Carvalho Silva et al., 2014; Lim et al., 2016b). On the other hand, starch grain accumulation was also observed in sites of less dense cytoplasm especially for bacterised calli treated with Z78 pellet cells (T4) and bacterised embryogenic calli treated with Z78 sonicated cells (T3). Moura et al. (2008) and Padua et al. (2013) highlighted that starch storage in the embryo, embryogenic cells or in adjacent cells indicates the acquisition of embryogenic competence, the starch
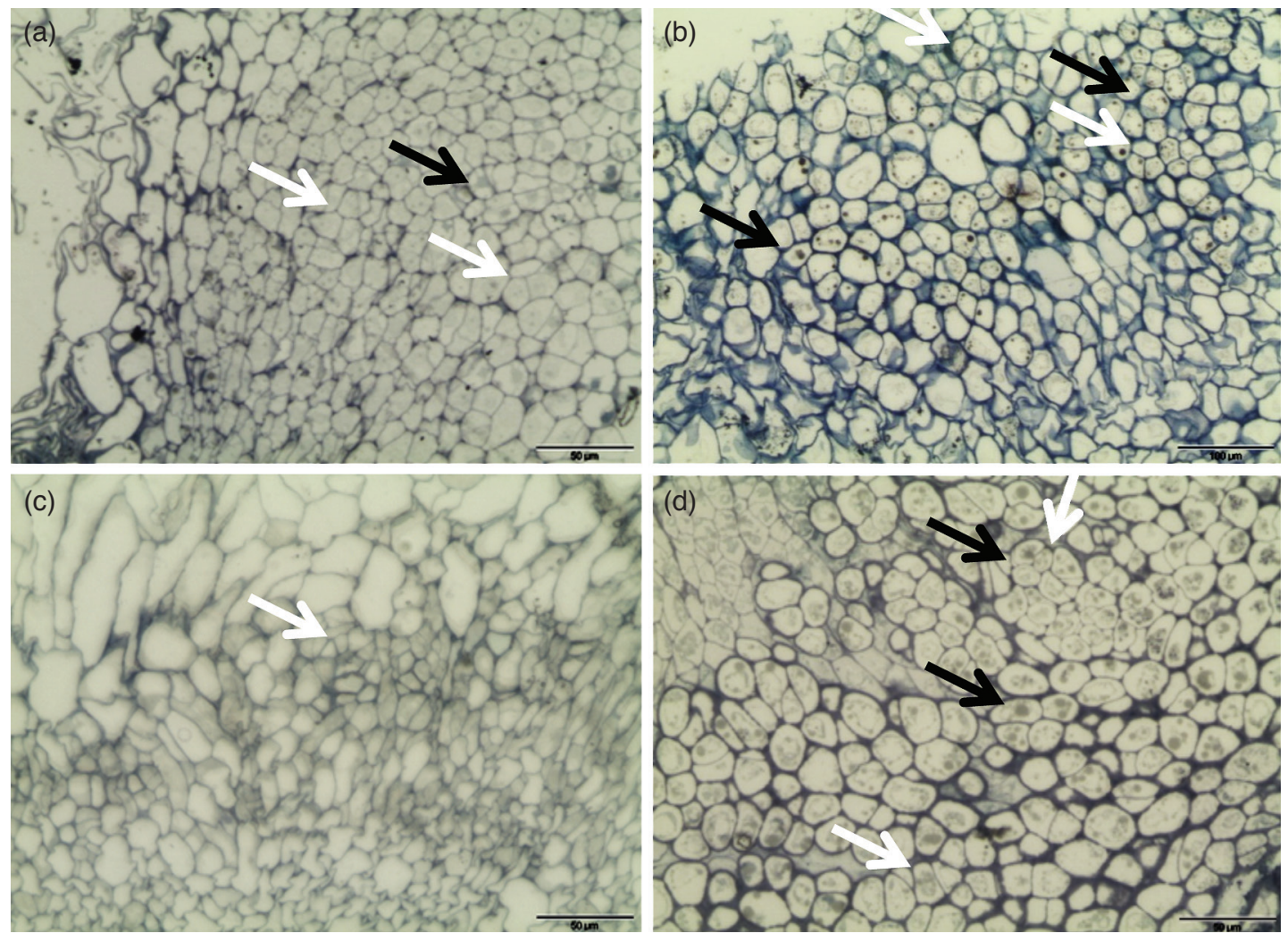

Figure 1. Microscopic appearance (longitudinal section) of (a) non-bacterised calli treated in 100\% (w/v) N+100\% (w/v) 2, 4-D (T1), (b) bacterised calli with Z78 pellet cells (T4), (c) non-bacterised embryogenic calli treated in $100 \%$ (w/v) N+100\% (w/v) 2, 4-D (T1) and (d) bacterised embryogenic calli with Z78 sonicated cells (T3). Bar, $50 \mu \mathrm{m}$; black arrow, starch accumulation; white arrow, isodiametric cell formation. 
grains being produced to support and initiate the development of somatic embryos. Our results suggest that cell differentiation and proliferation have occurred in the treated oil palm calli and embryogenic calli. Hovever, no accumulation of starch grain was observed in non-bacterised embryogenic calli treated with $100 \%$ (w/v) N + 100\% $(\mathrm{w} / \mathrm{v})$ 2, 4-D (Figures 1c) and little was observed in non-bacterised calli treated with $100 \%(\mathrm{w} / \mathrm{v}) \mathrm{N}+$ 100\% (w/v) 2, 4-D (Figure 1a).

Intriguingly, a rapid biomass increment was observed after 30 days for bacterised calli treated with Z78 pellet cells (T4) and bacterised embryogenic calli treated with Z78 sonicated cells (T3) (Figures $2 a$ and $2 b$ ). Inoculation of Z78 pellet cells (T4) showed superior effects in calli biomass increment compared to control treatment (Figure $2 a$ ). The increment of calli biomass for Z78 pellet cells (T4) inoculum with an average of $69.11 \%$ higher than the control supplied with $100 \%$ (w/v) N (T1) $(58.52 \%$ ) (Figure 2a). The result has highlighted that bacterised calli with Z78 pellet cells (T4) can increase the biomass calli rapidly compared to the conventional practice. This result corroborates with our previous study as reported by Lim et al. (2016b), whereby Z78 diazotroph has the ability to fix atmospheric nitrogen and subsequently accelerates the friable embryogenic calli formation during artificial symbiotic association. Maximum response on biomass increment was also observed for bacterised embryogenic calli treated with Z78 sonicated cells (T3) which was exceeding 100\% increment after 40 days of cultivation period (Figure 2b). Presumably, the release of intracellular components of the bacterial cells can eventually enhance cell differentiation and proliferation in calli and embryogenic calli by increasing the biomass as shown in Figures $2 a$ and $2 b$, respectively. Our results are in agreement with earlier finding by Janarthine and Eganathan (2012), the reintroduction of isolated endophytic bacteria into tissue culture materials can lead to improvement of plant growth.

For viable cell count analysis, throughout the experiment, the bacterial cell numbers remained

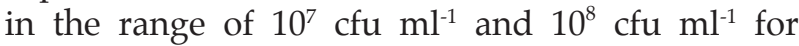
bacterised calli, embryogenic calli with $\mathrm{Z78}$ pellet cells (T4) and in $10^{4} \mathrm{cfu} \mathrm{ml}^{-1}$ for Z78 sonicated cells (T3) (Table 1). The viable cell count of bacterised embryogenic calli treated with Z78 pellets (T4) slightly decreased throughout the experiment period, while for bacterised calli with Z78 pellet cells (T4), the viable cell count decreased on the first 20 days of growth and gradually increased to 7.78 x $10^{7} \mathrm{cfu} \mathrm{ml}^{-1}$ at Day $60\left(\mathrm{D}_{60}\right)$ (Table 1). As the result revealed, Z78 bacterial cells could possibly create an artificial symbiotic relation with the calli and embryogenic calli tissues and without conferring pathogenesis. Our results are in agreement with an earlier finding by Preininger et al. (1997) wherein the fundamental of natural symbiosis interaction is able to create interdependency between the partners. Practically, the interdependency regulation of carbon and energy sources for both macro and micro-symbiont was able to create a most suitable artificial association condition.

\section{Biochemical Profile}

An understanding between the interactions of Z78 bacterial cells, oil palm calli and embryogenic calli with respect to sugars, phenolic compounds, amino acids and proteins accumulation during cells differentiation and proliferation is necessary. In most cases, phenolic compounds, sugars, amino acids and proteins not only act as cell metabolism

TABLE 1. VIABLE CELL COUNT OF TREATED CALLI AND EMBRYOGENIC CALLI AT $\mathrm{D}_{0}, \mathrm{D}_{20}, \mathrm{D}_{40}$ and $\mathrm{D}_{60}$

\begin{tabular}{|c|c|c|c|c|c|c|c|c|}
\hline \multirow[t]{3}{*}{ Treatments } & \multicolumn{7}{|c|}{ Viable cell count $\left(\mathrm{cfu} \mathrm{m}^{-1}\right)$} & \\
\hline & \multicolumn{4}{|c|}{ Calli } & \multicolumn{4}{|c|}{ Embryogenic calli } \\
\hline & $\mathrm{D}_{0}$ & $D_{20}$ & $\mathrm{D}_{40}$ & $D_{60}$ & $\mathrm{D}_{0}$ & $\mathrm{D}_{20}$ & $\mathbf{D}_{40}$ & $D_{60}$ \\
\hline $\begin{array}{c}\mathrm{T} 1: 100 \%(\mathrm{w} / \mathrm{v}) \\
\mathrm{N}+100 \%(\mathrm{w} / \mathrm{v}) \\
2,4-\mathrm{D}\end{array}$ & - & - & - & - & - & - & - & - \\
\hline $\begin{array}{c}\mathrm{T} 2: 25 \%(\mathrm{w} / \mathrm{v}) \\
\mathrm{N}+10 \%(\mathrm{w} / \mathrm{v}) \\
2,4-\mathrm{D}\end{array}$ & - & - & - & - & - & - & - & - \\
\hline $\begin{array}{c}\mathrm{T} 3: 25 \%(\mathrm{w} / \mathrm{v}) \\
\mathrm{N}+10 \%(\mathrm{w} / \mathrm{v}) \\
\text { 2,4-D + Z78 } \\
\text { sonicated cells }\end{array}$ & $3.33 \times 10^{4}$ & TFTC & TFTC & TFTC & $3.33 \times 10^{4}$ & $5.00 \times 10^{4}$ & $6.11 \times 10^{4}$ & $4.33 \times 10^{4}$ \\
\hline $\begin{array}{c}\mathrm{T} 4: 25 \%(\mathrm{w} / \mathrm{v}) \\
\mathrm{N}+10 \%(\mathrm{w} / \mathrm{v}) \\
\text { 2,4-D + Z78 } \\
\text { pellet cells }\end{array}$ & $9.00 \times 10^{8}$ & $5.33 \times 10^{7}$ & $6.00 \times 10^{7}$ & $7.78 \times 10^{7}$ & $9.00 \times 10^{8}$ & $7.11 \times 10^{8}$ & $5.22 \times 10^{8}$ & $3.33 \times 10^{8}$ \\
\hline
\end{tabular}

Note: * - Not detected; TFTC - too few to count; Dx - day of X. 

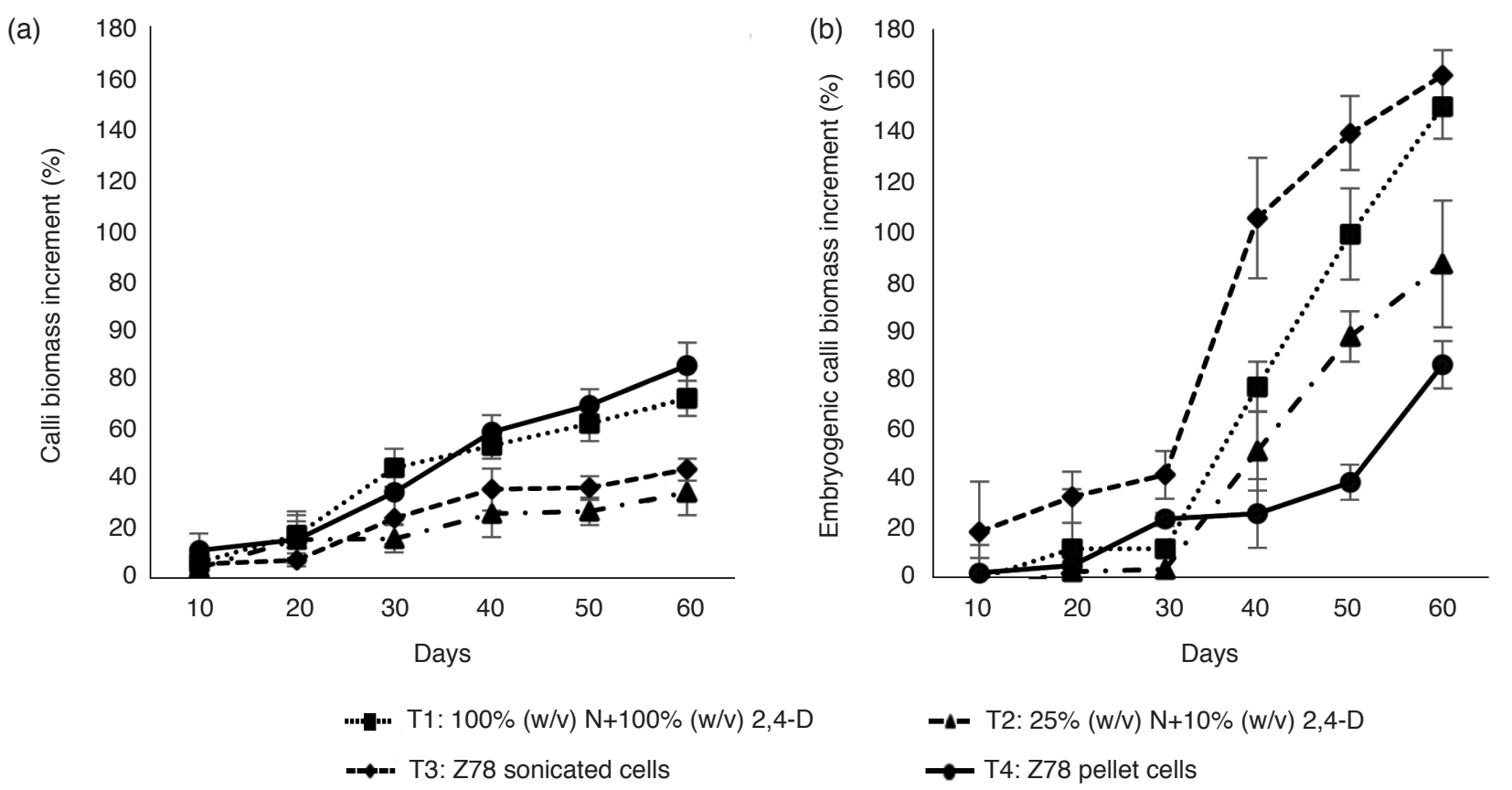

Note: T3 and T4 were also supplied with 25\% (w/v) N and 10\% (w/v) 2,4-D.

Figure 2. Biomass increment of treated (a) calli and (b) embryogenic calli in every 10 days interval and up to 60 days of incubation periods.

regulators, but also have an impact on plant developmental processes. Based on Gomes et al. (2014), biochemical variations of sugars, starch and amino acids at different stages of oil palm somatic embryogenesis are important to monitor progress of embryogenic formation. This can indirectly gain useful biochemical information to identify and characterise progress of somatic embryogenesis. It is presumed that the alteration of the metabolites might be due to the diazotroph inoculation which could probably promote cells differentiation and proliferation processes for both calli and embryogenic calli of the tested oil palm cultures.

\section{Total Amino Acid Contents}

With reference to Figure $3 a$, the amino acid levels of bacterised calli treated with Z78 pellet cells (T4) significantly increased from Day $10\left[\left(\mathrm{D}_{10}\right)\right.$ $\left(0.45 \mathrm{mg}(\mathrm{g} \mathrm{FW})^{-1}\right]$ to Day $30\left[\left(\mathrm{D}_{30}\right)\left(1.90 \mathrm{mg}(\mathrm{g} \mathrm{FW})^{-1}\right]\right.$, then decreased at Day $50\left(\mathrm{D}_{50}\right)\left[0.68 \mathrm{mg}(\mathrm{g} \mathrm{FW})^{-1}\right]$ and gradually increased up to $0.85 \mathrm{mg}(\mathrm{g} \mathrm{FW})^{-1}$ on $\mathrm{D}_{60}$ of cultivation. The increment of total free amino acids in the bacterised calli tissue could be attributed to the increase of metabolic activities of the plant cultures which lead to cell division in somatic embryogenesis and cell biomass increment (Feher et al. 2003). Feher et al. (2003) also found an increment in total amino acids of cell tissue which may correlate with the increase of plant metabolic activities. However, amino acid is associated with many functions such as the primary product of nitrogen metabolism, it is also involved directly and indirectly in protein synthesis which participate in many aspects of plant development and growth (Vidal and Gutierrez, 2008). It has therefore been speculated that bacterised calli utilised the amino acid for protein synthesis during the cultivation period, thus a drastic decline of amino acid from $\mathrm{D}_{30}$ to $D_{50}$ was observed in this study. Overall, bacterised calli (T3, T4) showed lower levels of amino acid concentrations compared to the non-bacterised calli (T1, T2).

Yet, for bacterised embryogenic calli treated with Z78 sonicated cells (T3), the amino acid levels drastically declined from $\mathrm{D}_{10}$ with $3.03 \mathrm{mg}(\mathrm{g} \mathrm{FW})^{-1}$ to $0.89 \mathrm{mg}(\mathrm{g} \mathrm{FW})^{-1}$ then $1.14 \mathrm{mg}\left(\mathrm{g} \mathrm{FW}^{-1}\right.$ and rapidly increased to $3.6218 \mathrm{mg}(\mathrm{g} \mathrm{FW})^{-1}$ at Day $40\left(\mathrm{D}_{40}\right)$, subsequently decreased to $1.81 \mathrm{mg}\left(\mathrm{g} \mathrm{FW}^{-1}\right.$ and 1.46 $\mathrm{mg}(\mathrm{g} \mathrm{FW})^{-1}$ in $\mathrm{D}_{50}$ and $\mathrm{D}_{60}$ of cultivation (Figure $3 b$ ). Similar results were also reported by Santa-Catarina et al. (2004) for Ocotea catharinensis embryogenic cultures, whereby there was an increase of total amino acids level in the first week of culture and followed by a significant decrease. The decline in amino acid contents was due to the increasing complexities in embryogenic process for the treated embryogenic calli. It is also believed that amino acids production decreased during the progress of regeneration and maturation of embryos in order to support cells development. This result corroborates with the work of Booz et al. (2009) which reported a continuous decrease of the total free amino acid levels throughout the stages of differentiation in embryogenesis of Acca sellowiana Berg. As mentioned previously, amino acid is important for nitrogen 
(a)



血 T1: $100 \%(w / v) ~ N+100 \%(w / v) 2,4-D$

目 T3: Z78 sonicated cells (b)

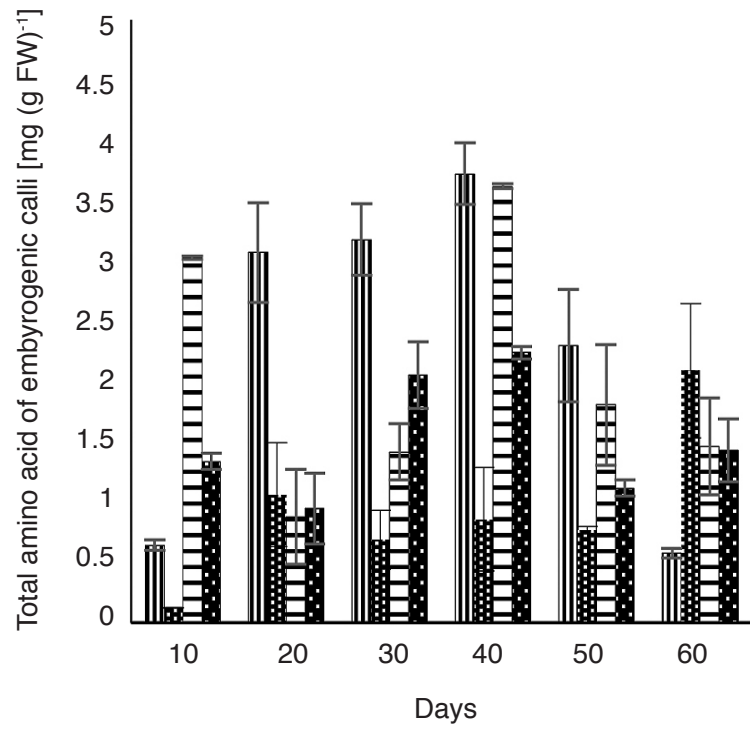

T2: $25 \%(w / v) ~ N+10 \%(w / v) ~ 2,4-D$

T4: Z78 pellet cells

Note: T3 and T4 were also supplied with 25\% (w/v) N and 10\% (w/v) 2,4-D.

Figure 3. Total amino acid contents of treated (a) calli and (b) embryogenic calli of oil palm during 60 days of cultivation period. FW, fresh weight.

transport in cells, it also plays a vital role in protein synthesis to support plant growth and development (Vidal and Gutierrez, 2008). Hence, it explains the drastic decline of amino acid from $\mathrm{D}_{10}$ to $\mathrm{D}_{20}$ and $\mathrm{D}_{40}$ to $\mathrm{D}_{50}$ in this study (Figure $3 b$ ). On the other hand, the accumulation of high amount of amino acid for bacterised embryogenic calli with Z78 sonicated cells at $D_{40}$ could be associated with the nitrogen sources produced by Z78 bacterial cell. At this point, it is important to highlight that the ability of Z78 bacterial cells to fix atmospheric nitrogen and indole3 -acetic acid (IAA) synthesis (type of auxin that has been implicated in most of the quantitative growth changes) (Davies, 2010), involving amino acid and protein conjugation and degradation. It is believed that the presence of the fixed nitrogen, favouring the amino acid production as ammonia is the source of nitrogen for all the amino acid. Wherein, the stimulation and signalling of auxin may involve the IAA-amino acid conjugation process and also auxin responsive AUX/IAA protein (Caboche et al., 1984; Feher et al., 2003).

\section{Total Protein Contents}

Throughout the cultivation period, a higher protein level was detected for bacterised calli with Z78 sonicated cells (T3) and Z78 pellet cells (T4) in comparison to the non-bacterised calli (T1, T2). For calli treated with $100 \%(\mathrm{w} / \mathrm{v}) \mathrm{N}+100 \%$ (w/v) 2, 4-D (T1), $25 \%(\mathrm{w} / \mathrm{v}) \mathrm{N}+10 \%(\mathrm{w} / \mathrm{v}) 2.4-\mathrm{D}(\mathrm{T} 2)$ and Z78 sonicated cells (T3), protein contents stabilised after 20 days of cultivation. Particularly, for bacterised calli with Z78 pellet cells (T4), the protein contents increased gradually from $\mathrm{D}_{20}\left[7.18 \mathrm{mg}(\mathrm{g} \mathrm{FW})^{-1}\right]$ to $\mathrm{D}_{50}\left[10.65 \mathrm{mg}(\mathrm{g} \mathrm{FW})^{-1}\right]$ (Figure 4a). The increased concentration of total protein contents during the progression of the embryogenic development stages was also previously reported by CangahualaInocente et al. (2009) in Acca sellowiana. In addition, a decline in amino acid contents was also observed when the concentration of proteins increased (Figures 3 and 4). Thus, it is believed that protein synthesis has taken part during this cultivation period. In turn, the reduction of protein contents from $\mathrm{D}_{50}\left[10.65 \mathrm{mg}\left(\mathrm{g} \mathrm{FW}^{-1}\right]\right.$ to $\mathrm{D}_{60}(8 \mathrm{mg}(\mathrm{g} \mathrm{FW})$ $\left.{ }^{1}\right]$ was detected for the bacterised calli treated with Z78 pellet cells (T4). The reduction in protein levels could be due to the consumption to activate cellular metabolism for the establishment of embryogenic competence (Gutmann et al., 1996). These results evidently show that the embryogenic development process has occurred rapidly in the bacterised plant cell during the symbiotic association as the protein synthesis took place.

Apart from that, the treated embryogenic calli showed a gradual decrease of protein content for almost all treatments starting from $D_{30}$ except for embryogenic calli treated with Z78 sonicated cells (T3). The protein contents of bacterised embryogenic calli with Z78 sonicated cells (T3) then slightly increased from $\mathrm{D}_{30}\left[10.76 \mathrm{mg}\left(\mathrm{g} \mathrm{FW}^{-1}\right]\right.$ to $\mathrm{D}_{40}\left[13.61 \mathrm{mg}(\mathrm{g} \mathrm{FW})^{-1}\right]$ and gradually declined again to $7.56 \mathrm{mg}(\mathrm{g} \mathrm{FW})^{-1}$ in $\mathrm{D}_{60}$ of cultivation period (Figure $4 b$ ). This observation suggested that the bacterised embryogenic calli treated with Z78 
(a)

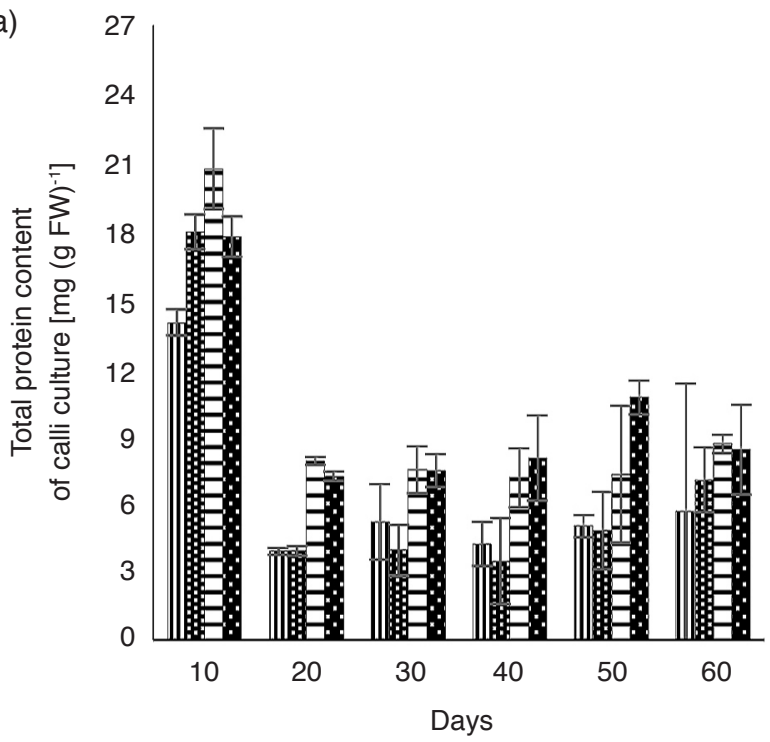

血 T1: 100\% (w/v) N+100\% (w/v) 2,4-D

目 T3: Z78 sonicated cells (b)

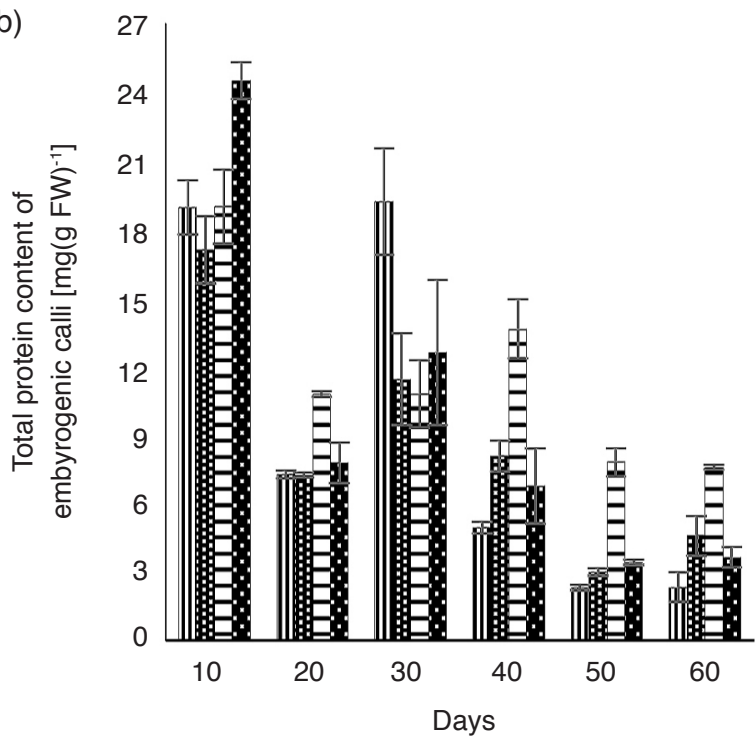

佣 $\mathrm{T} 2: 25 \%(\mathrm{w} / \mathrm{v}) \mathrm{N}+10 \%(\mathrm{w} / \mathrm{v}) 2,4-\mathrm{D}$

T4: Z78 pellet cells

Note: T3 and T4 were also supplied with 25\% (w/v) N and 10\% (w/v) 2,4-D.

Figure 4. Total protein contents of treated (a) calli and (b) embryogenic calli of oil palm during 60 days of cultivation period. FW, fresh weight.

sonicated cells (T3) started to form embryo and towards the embryo maturation phase more rapidly compared to normal cultivation practice. A similar observation was also reported by Gomes et al. (2014), whereby the total protein levels have slightly declined during the embryo maturation phase. With the release of cellular components and protein from sonicated Z78, this can eventually enhance the growth of embryogenic calli. According to Lim et al. (2016a, b), the mechanically lysed bacterial cells can release certain cellular components and further increase in vitro oil palm tissues differentiation. Previous studies of Aberlenc-Bertossi et al. (2008) and Sghaier-Hammami et al. (2009) also showed that at the stage of embryo maturation, proteins of the glycolytic pathway as well as storage proteins started to express in Phoenix dactylifera and Elaeis guineensis, respectively. These reports suggested that protein utilisation may take place in embryogenic calli, which might be essential for the differentiation of somatic embryos. Hereafter, this could explain that the protein accumulation decreased during the embryo maturation for the bacterised oil palm embryogenic calli.

\section{Total Phenolic Compounds}

In view of the results obtained upon evaluating the phenolic compounds produced, the bacterised calli treated with Z78 pellet cells (T4) showed the highest total phenolic compounds amongst the treatments from $D_{20}$ to $D_{50}$ of cultivation period (Figure 5a). At the same time, the same treatment
(T4) had also promoted the highest increment of calli biomass (Figure 2a). Therefore, we presume that the detected phenolic compounds here might be classified as monophenol which is a type of phenolic compound that could enhance cell growth. According to Arnaldos et al. (2001) and Ozyigit (2008), some monophenols may inhibit enzymatic oxidation of IAA and this eventually resulted in rapid cell division and cell elongation. In certain studies, phenolic compounds were also introduced into the plant cultures as growth promoters in order to achieve higher biomass production, such as in Hypeicum perforatum L. and Feijoa sellowiana Berg (Reis et al., 2008; Franklin and Dias, 2011). For all the calli cultures, it was also observed that the phenolics content increased from $\mathrm{D}_{0}$ to $\mathrm{D}_{30}$ and gradually decreased during the last 20 days $\left(D_{40}\right.$ $\mathrm{D}_{60}$ of cultivation). In most cases, calli conversion into somatic embryo is characterised by a decline of phenolics content. During this period, phenolics may act as substrate for oxidative enzymes, leaving auxin free to promote embryo differentiation (Ndoumou et al., 1997).

In this study, the concentrations of phenolic compound were over 10-fold higher in the embryogenic calli compared to calli in the first 10 days of cultivation (Figures $5 a$ and $5 b$ ). The introduction of Z78 sonicated cells (T3) and Z78 pellet cells (T4) into the embryogenic calli, wherein it required more time to adapt in the new cultivation condition compared to calli culture, although this is very much a speculation. Based on Reis et al. (2008) and Ozyigit (2008), phenolic compounds are often 
associated with somatic embryo formation and also play an important role in plant defence mechanism. Hence, it is believed that during the introduction of Z78 sonicated cells (T3) and Z78 pellet cells (T4) into the embryogenic calli, it triggered the plant defence mechanism. However, after the symbiotic association was successfully created after a certain period of cultivation, the phenolic compounds were reduced. In addition, phenolic compounds may also act as molecular bridges between cell wall components and increase the rigidity of plant cell walls (Fry, 1986; Ozyigit, 2008). Embryogenic calli consist of protoderm which is the cell wall for the tissues, whereas calli only form up by unorganised cell with meristematic masses. Therefore, it is not surprising that this metabolite was accumulated at high amount in the embryogenic calli cultures during the study.

The levels of phenolic compound for bacterised embryogenic calli with Z78 sonicated cells (T3) dropped drastically from $2.36 \mathrm{mg}(\mathrm{g} \mathrm{FW})^{-1}$ to 0.21 $\mathrm{mg}(\mathrm{g} \mathrm{FW})^{-1}$. Same trend was also visualised for the embryogenic calli treated with $100 \%(\mathrm{w} / \mathrm{v}) \mathrm{N}$ $+100 \%$ (w/v) 2, 4-D (T1) and Z78 pellet cells (T4). However, the levels of phenolic compounds detected in bacterized embryogenic calli treated with Z78 sonicated cells (T3) were higher than the bacterised embryogenic calli treated with Z78 pellet cells (T4) throughout the 60 days of cultivation (Figure $5 b$ ). This observation corresponds to our previous studies (Lim et al., 2016a, b), whereby embryogenic calli of oil palm fruit forms (tenera and dura) treated with Z78 sonicated cells (T3) have better growth traits compared to the rest of the treatments. This has directly implied the ability of Z78 sonicated cells treatment (T3) to promote cells differentiation of embryogenic calli of oil palm and finally generate more embryo. Based on Reis et al. (2008), phenolic compounds are often associated with somatic embryo formation. For example, Ndoumou et al. (1997) studied the differentiation of somatic embryos in cacao is concomitant during a decline of phenolic production. Nevertheless, phenolics could interfere with auxin metabolism, keeping auxin at concentration particularly favourable for embryoid induction (Reis et al., 2008). Flavonoid, a type of phenolic, was reported to influence the cell division by regulating the auxin transport, directly involved in cell regulation and also in bacteria colonisation (Ferguson and Mathesisu, 2003; Steenhoudt and Vanderleyden, 2000). Additionally, phenolics can also be metabolised by diazotroph itself, it was postulated that the production of phenolics may act as alternative carbon sources (Chan, 1986). The microbial conjugation of phenylpropanoid signal produced in plant via shikimic acid may be one of the important aspects in the establishment of symbiotic interaction (Mandal et al., 2010).

\section{Total Sugar Levels}

A significant variation was detected in total sugar levels at different treatments within the 60 days of calli cultivation. The highest sugar contents were noticed in $\mathrm{D}_{20}$ and $\mathrm{D}_{30}$ of calli cultured in $100 \%$ $(\mathrm{w} / \mathrm{v}) \mathrm{N}+100 \%$ (w/v) 2, 4-D (T1). Almost all the treatments of calli showed a slow decline for total sugar levels (Figure 6a). Total sugar is important

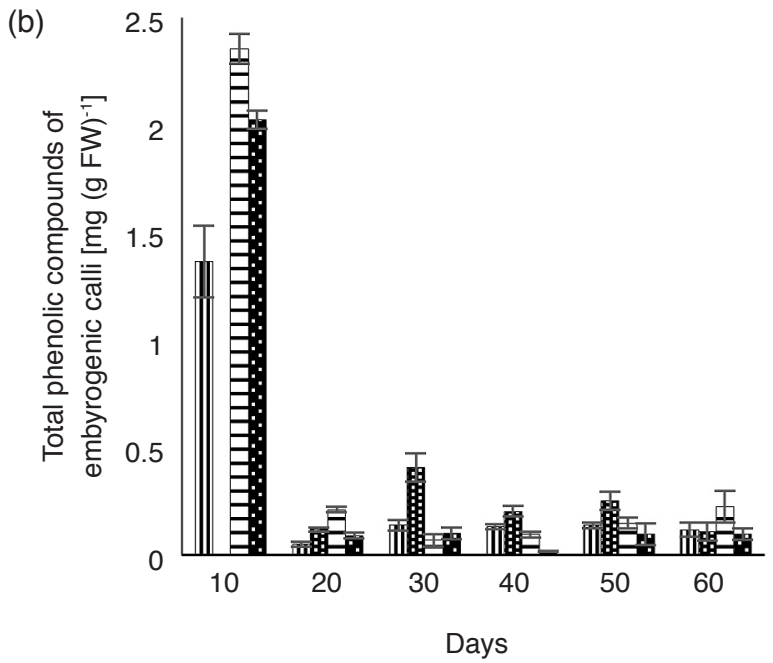

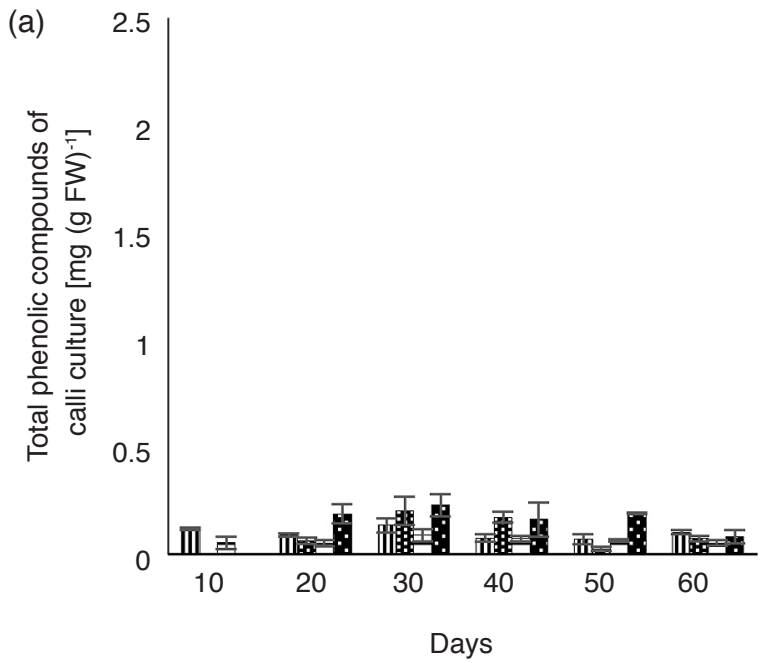

T1: $100 \%(w / v) ~ N+100 \%(w / v) 2,4-D$

目 T3: Z78 sonicated cells
T2: $25 \%(w / v) ~ N+10 \%(w / v) 2,4-D$

T4: Z78 pellet cells

Note: T3 and T4 were also supplied with $25 \%(\mathrm{w} / \mathrm{v}) \mathrm{N}$ and $10 \%(\mathrm{w} / \mathrm{v}) 2,4-\mathrm{D}$.

Figure 5. Total phenolic compounds of treated (a) calli and (b) embryogenic calli of oil palm during 60 days of cultivation period. FW, fresh weight. 
to act as the carbon source for the synthesis of polysaccharide. According to Drogue et al. (2012), sugar in specific bacterial lipopolysaccharide was involved in plant-microbes colonisation and attachment. This is a crucial source in creating a system of plant-microbes symbiosis between the in vitro oil palm cultures and bacterial cell. During the initial part of calli differentiation at $\mathrm{D}_{30}$, total sugar levels declined steeply from peak at $1.54 \mathrm{mg}(\mathrm{gFW})^{-1}$ to $1.05 \mathrm{mg}(\mathrm{g} \mathrm{FW})^{-1}$ for calli cultured with $100 \%$ (w/v) $\mathrm{N}+100 \%$ (w/v) 2, 4-D (T1). A similar trend was also observed for the calli treated with $\mathrm{Z78}$ pellet cells (T4), the sugar levels gradually reduced from $1.02 \mathrm{mg}(\mathrm{g} \mathrm{FW})^{-1}$ to $0.69 \mathrm{mg}(\mathrm{g} \mathrm{FW})^{-1}$. These data suggest that bacterised calli required more energy to differentiate and begin the synthesis of embryogenic calli. A study by Baud et al. (2002) showed that mobilisation of sugars in the beginning stage of embryogenic development is very important as the sugars mainly act as the sources of metabolic energy for carbon skeletons and for signalling process. Interestingly, only calli treated with Z78 sonicated cells (T3) presented a reverse effect, more precisely, whereby the sugar levels increased from $0.85 \mathrm{mg}$ ( $\mathrm{g}$ $\mathrm{FW})^{-1}$ at $\mathrm{D}_{10}$ to $1.28 \mathrm{mg}(\mathrm{g} \mathrm{FW})^{-1}$ at $\mathrm{D}_{60}$ (Figure $6 a$ ). However, it is difficult to differentiate between the metabolic and regulatory functions of sugars in the plant cell, the indirect alteration of the sugar metabolism may also affect the morphogenesis of the plant cell (Lozovaya et al., 2006).

Although there were no distinctive changes in the total sugar levels for bacterised embryogenic calli, embryogenic calli treated with Z78 pellet cells (T4) showed a slight increment of total sugar levels

(a)

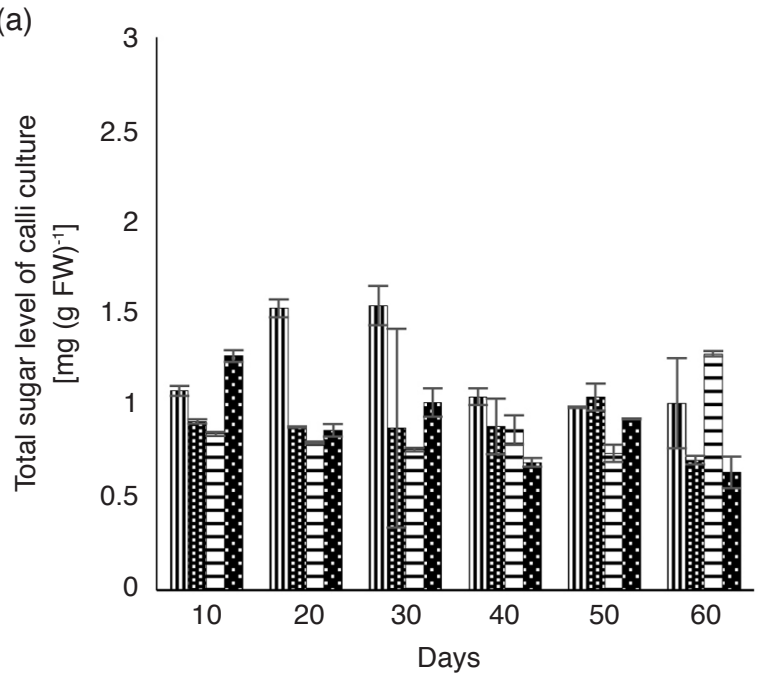

血 T1: 100\% (w/v) N+100\% (w/v) 2,4-D

目 T3: Z78 sonicated cells

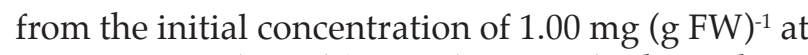
$\mathrm{D}_{10}$ to $1.39 \mathrm{mg}(\mathrm{g} \mathrm{FW})^{-1}$ at $\mathrm{D}_{60}$ (Figure $6 b$ ). Throughout the process of regeneration and differentiation of embryogenic calli from the 60 days of cultivation, the amount of sugars in the bacterised embryogenic calli treated with Z78 sonicated cells (T3) significantly increased, achieving as high as 1.96 $\mathrm{mg}(\mathrm{g} \mathrm{FW})^{-1}$ for the first 40 days of cultivation, but gradually reduced at $\mathrm{D}_{50}$ and $\mathrm{D}_{60}$. Gomes et al. (2014) and Warchol et al. (2015) also observed similar results with the increase of total soluble sugar levels during the early stage of maturation for the somatic embryos in Elaeis guineensis and Cordyline australis. The result in this present study can be explained, at least in part, through the rapid cell differentiation that only occurred for the bacterised embryogenic calli with Z78 sonicated cells (T3), whereby the bacterised embryogenic calli started to evolve into compressed embryo, globular and finger like appearance after 30 days of cultivation. According to Gomes et al. (2014), the concentration of soluble sugar may gradually increase during the maturation stage of embryos. In general, sucrose present in the medium comes into the metabolism, providing the reducing sugars to calli after breaking into glucose and fructose (Santos Filho et al., 2014). From the results obtained, we come to realise that the inoculation of Z78 sonicated cells (T3) may induce the cell differentiation and increase the total sugar accumulation in bacterised oil palm embryogenic calli (Figure 6b). However, the understanding of in vitro plant tissue culture materials and microbes interaction towards the sugar accumulation is rather sparse. More studies

(b)



Note: T3 and T4 were also supplied with 25\% (w/v) N and 10\% (w/v) 2,4-D.

Figure 6. Total sugar levels of treated (a) calli and (b) embryogenic calli of oil palm during 60 days of cultivation period. FW, fresh weight. 
need to be conducted in order to yield new insight and a better comprehension towards the interrelation.

\section{CONCLUSION}

In conclusion, the presented results may provide a better understanding for the interaction of biochemical and physiological changes that occur during somatic embryogenesis of treated in vitro oil palm calli and embryogenic calli. The reduction of total sugar levels and increment of phenolics, amino acid and protein in calli especially for calli treated with Z78 pellet cells (T4) would possibly explain the rapid progression during the embryogenic development of the bacterised calli, whereas the high content of phenolics, total sugar levels and reduction of amino acid and protein in treated embryogenic calli with Z78 sonicated cells (T3) would explain the accelerated regeneration and maturation of embryos. To our knowledge, this is the first report for the biochemical profiling on in vitro plant-bacterium interactions. We firmly believe that this study may provide a better understanding and as a fundamental guideline on oil palm somatic embryogenesis and in vitro plant-bacterium interactions for the future studies.

\section{ACKNOWLEDGEMENT}

The experiment was financed by research university grant $1001 /$ PBIOLOGI/815088. Authors acknowledged the support of the School of Biological Sciences, Universiti Sains Malaysia, Pulau Pinang for the research facilities; and also many thanks to the Advanced Biotechnology and Breeding Centre (ABBC), MPOB, for the oil palm planting materials. We also thank Dr Umi Salamah Ramli, Head of Metabolics Unit, $\mathrm{ABBC}$, MPOB for reviewing this manuscript.

\section{REFERENCES}

ARNALDOS, T L; MUNOZ, R; FERRER, $\mathrm{M}$ A and CALDERON, A A (2001). Changes in phenol content during strawberry (Fragaria $x$ ananasa, $\mathrm{cv}$. Chandler) callus culture. Physiol Plant. Vol. 113(3): 315-322.

BALZON, T A; LUIS, Z G and SCHERWINSKIPEREIRA, J E (2013). New approaches to improve the efficiency of somatic embryogenesis in oil palm (Elaeis guineensis Jacq.) from mature zygotic embryos. In vitro Cell Dev. Biol. Plant. Vol. 49(1): 41-50.

BAUD, S; BOUTIN, J P; MIQUEL, M; LEPINIEC, $\mathrm{L}$ and ROCHAT, C (2002). An integrated overview of seed development in Arabidopsis thaliana ecotype WS. Plant Physiol Biochem. Vol. 40(2): 151-160.
BOLOURI-MOGHADDAM, M R and VAN DEN ENDE, W (2012). Sugars and plant innate immunity. J. Exp. Bot. Vol. 63(11): 3989-3998.

BOOZ, M R; KERBAUY, Y G B; GUERRA, M P and PESCADOR, R (2009). The role of c-aminobutyric acid (Gaba) in somatic embryogenesis of Acca sellowiana Berg. (Myrtaceae). Braz J. Plant Physiol. Vol. 21(4): 271-280.

BRADFORD, M M (1976). A rapid and sensitive method for the quantitation of microgram quantities of protein utilizing the principle of protein-dye binding. Anal Biochem. Vol. 72(1-2): 248-254.

CABOCHE, M; ARANDA, G; POLL, A M; HUET, J C and LEGUAY, J J (1984). Auxin conjugation by tobacco mesophyll protoplasts: Correlations between auxin cytotoxicity under low density growth conditions and induction of conjugation processes at high density. Plant Physiol. Vol. 75(1): 54-59.

CANGAHUALA-INOCENTE, G C; STEINER, N; MALDONADO, S B and GUERRA, M P (2009). Patterns of protein and carbohydrate accumulation during somatic embryogenesis of Acca sellowiana. Pesq. Agropec Bras. Vol. 44(3): 217-224.

CHAN, Y K (1986). Utilization of simple phenolics for dinitrogen fixation by soil diazotrophic bacteria. Plant Soil Vol. 90(1/3): 141-150.

DAVIES, P J (2010). Plant Hormones: Biosynthesis, Signal Transduction, Action! Revised $3^{\text {rd }}$ edition. Dordrecht: Springer. p. 36-62.

DE CARVALHO SILVA, R; LUIS, Z G and SCHERWINSKI-PEREIRA, J E (2014). The histodifferentiation events involved during the acquisition and development of somatic embryogenesis in oil palm (Elaeis guineensis Jacq.). Plant Growth Regul. Vol. 72(1): 67-80.

DROGUE, B;DORÉ,H;BORLAND, S; WISNIEWSKIDYÉ, F and PRIGENT-COMBARET, C (2012). Which specificity in cooperation between phytostimulating rhizobacteria and plants? Res Microbiol. Vol. 163(8): 500-510

DUBOIS, M; GILLES, K A; HAMILTON, J K; REBERS, P and SMITH, F (1956). Colorimetric method for determination of sugars and related substances. Anal Chem. Vol. 28(3): 350-356.

DYKSTRA, M J (1992). Biological Electron Microscopy, Theory, Techniques and Troubleshooting. Plenum Press, New York. 
FEHER, A; PASTERNAK, T P and DUDITS, D (2003). Transition of somatic plant cells to an embryogenic state. Plant Cell Tissue Organ Cult. Vol. 74(3): 201-228.

FERGUSON, B J and MATHESIUS, U (2003). Signaling interactions during nodule development. Plant Growth Regul. Vol. 22(1): 47-72.

FRANKLIN, G and DIAS, A C P (2011). Chlorogenic acid participates in the regulation of shoot, root and root hair development in Hypericum perforatum. Plant Physiol Biochem. Vol. 49(8): 835-842.

FRY, S C (1986). Cross-linking of matrix polymers in the growing cell walls of angiosperms. Annu. Rev Plant Physiol. Vol. 37(1): 165-186.

GLAUERT, A M (1980). Fixation, dehydration and embedding of biological specimens, Practical Methods in Electron Microscopy. Elsevier, New York.

GOMES, H T; BARTOS, P M C; SILVA, C O; DO AMARAL, L I V and SCHERWINSKI-PEREIRA, J E (2014). Comparative biochemical profiling during the stages of acquisition and development of somatic embryogenesis in African oil palm (Elaeis guineensis Jacq.). Plant Growth Regul. Vol. 74(2): 199-208.

GUEDES, R; DA SILVA, T L; LUIS, Z G and SCHERWINSKI-PEREIRA, J E (2013). Initial requirements for embryogenic calluses initiation in thin cell layers explants from immature female oil palm inflorescences. Afr. J. Biotechnol. Vol. 10(52): 10774-10780.

GUTMANN, M; VON ADERKAS, P; LABEL, P and LELU, M A (1996). Effects of abscisic acid on somatic embryo maturation of hybrid larch. J. Exp. Bot. Vol. 47(12): 1905-1917.

JANARTHINE, $S$ and EGANATHAN, P (2012). Plant growth promoting of endophytic Sporosarcina aquimarina SjAM16103 isolated from the pneumatophores of Avicennia marina L. Int. J. Microbiol. Vol. 2012: 1-10.

JIMÉNEZ, V M (2001). Regulation of in vitro somatic embryogenesis with emphasis on the role of endogenous hormones. Rev Bras Fisiol Veg Vol. 13(2): 196-223.

KEYEO, F; AI'SHAH, O N and AMIR, H G (2011). Diazotroph in promoting growth of rice seedlings. Biotech. Vol. 10(3): 267-273.

KUMAR, S P and KUMARI, B D R (2011). Factors affecting on somatic embryogenesis of safflower (Carthamus tinctorius L.) at morphological and biochemical levels. World J. Agric. Sci. Vol. 7(2): 197-205.
LEE, Y P and TAKAHASHI, T (1966). Improved calorimetric determination of amino acids with the use of ninhydrin. Anal Biochem. Vol. 14(1): 71-77.

LIM, S L; NABILA, H M N; ATIQAH, S; SUBRAMANIAM, S; CHAN, L K; ZAMZURI, I and AMIR, H G (2016a). Artificial symbiotic association and growth induction of embryogenic calli (Elaeis guineensis Jacq.) inoculated with Herbaspirillum seropedicae (Z78). Malays, J. Microbiol. Vol. 12(6): 485-491.

LIM, S L; SUBRAMANIAM, S; ZAMZURI, I and AMIR, H G (2016b). Biotization of in vitro calli and embryogenic calli of oil palm (Elaeis guineensis Jacq.) with diazotrophic bacteria Herbaspirillum seropedicae (Z78). Plant Cell Tissue Organ Cult. Vol. 127(1): 251-262.

LIM, S L; SUBRAMANIAM, S; ZAMZURI, I and AMIR, H G (2018). Growth and biochemical profiling of artificially associated micropropagated oil palm plantlets with Herbaspirillum seropedicae. J. Plant Interact. Vol. 13(1): 173-181.

LOZOVAYA, V; ULANOV, A; LYGIN, A; DUNCAN, D and WIDHOLM, J (2006). Biochemical features of maize tissues with different capacities to regenerate plants. Planta. Vol. 224(6): 1385-1399.

MANDAL, S M; CHAKRABORTY, D and DEY, S (2010). Phenolic acids act as signaling molecules in plant-microbe symbioses. Plant Signal Behav. Vol. 5(4): 359-368.

MARTIN, A B; CUADRADO, Y; GUERRA, H; GALLEGO, P; HITA, O; MARTIN, L; DORADO, $A$ and VILLALOBOS, $N$ (2000). Differences in the contents of total sugars, reducing sugars, starch and sucrose in embryogenic and non-embryogenic calli from Medicago arborea L. Plant Sci. Vol. 154(2): 143-151.

MCDOWELL, E M and TRUMP, B F (1976). Histologic fixatives suitable for diagnostic light and electron microscopy. Arch. Pathol. Lab. Med. Vol. 100(8): 405-414.

MILES, A A; MISRA, S S and IRWIN, J O (1938). The estimation of the bactericidal power of the blood. Int. J. Hyg. Vol. 38(6): 732-749.

MOURA, E F; VENTRELLA, M C; MOTOIKE, S Y; DE SÁ JÚNIOR, A Q; CARVALHO, $M$ and MANFIO, C E (2008). Histological study of somatic embryogenesis induction on zygotic embryos of macaw palm [Acrocomia aculeata (Jacq.) Lodd. ex Martius]. Plant Cell Tissue Organ Cult. Vol. 95(2): 175184.

MURASHIGE, T and SKOOG, F (1962). A revised medium for rapid growth and bioassays with tobacco tissue culture. Physiol Plant. Vol. 15(3): 473-497. 
NDOUMOU, DO; NDZOMO, G T and NIEMENAK, $N$ (1997). Phenol content, acidic peroxidase and IAA-oxidase during somatic embryogenesis in Theobroma cacao L. Biol Plantarum. Vol. 39(3): 337347.

NOWAK, J (1998). Benefits of in vitro 'Biotization' of plant tissue cultures with microbial inoculants. In vitro Cell Dev Biol. Vol. 34(2): 122-130.

OKON, Y; ALBRECHT, S L and BURRIS, R H (1977). Methods for growing Azospirillum lipoferum and for counting it in pure culture and in association with plants. Appl. Environ. Microbiol. Vol. 33(1): 85-88.

OLIVEIRA, A D; URQUIAGA, S; DÖBEREINER, J and BALDANI, J I (2002). The effect of inoculating endophytic $\mathrm{N}_{2}$-fixing bacteria on micropropagated sugarcane plants. Plant Soil Vol. 242(2): 205-215.

OZYIGIT, I I (2008). Phenolic changes during in vitro organogenesis of cotton (Gossypium hirsutum L.) shoot tips. Afr. J. Biotechnol. Vol. 7(8): 1145-1150.

PADUA, $\mathrm{M}$ S; PAIVA, L V; LABORY, C R; ALVES, E and STEIN, V C (2013). Induction and characterization of oil palm (Elaeis guineensis Jacq.) pro-embryogenic masses. An. Acad Bras Ciênc. Vol. 85(4): 1545-1556.

PARRAY, J A; KAMILI, A N; RESHI, Z A; QADRI, R A and JAN, S (2015). Interaction of rhizobacterial strains for growth improvement of Crocus sativus L. under tissue culture conditions. Plant Cell Tissue Organ Cult. Vol. 121(2): 325-334.

PREININGER, É; ZATYKO, J; SZUCS, P; KORANYI, $P$ and GYURJAN, I (1997). In vitro establishment of nitrogen-fixing strawberry (Fragaria $\mathrm{x}$ annassa) via artificial symbiosis with Azomonas insignis. In vitro Cell Dev Biol. Vol. 33(3): 190-194.

REIS, E; BATISTA, M T and CANHOTO, J M (2008). Effect and analysis of phenolic compounds during somatic embryogenesis induction in Feijoa sellowiana Berg. Protoplasma. Vol. 232(3): 193-202.

SANTA-CATARINA, C; HANAI, L R; DORNELAS, M C; VIANA, A M and FLOH, E I (2004). SERK gene homolog expression, polyamines and amino acids associated with somatic embryogenic competence of Ocotea catharinensis Mez. (Lauraceae). Plant Cell Tissue Organ Cult. Vol. 79(1): 53-61.

SANTOS FILHO, P R D; SANTOS, B R; BARBOSA, S; VIEIRA, L R; FREITAS, N C D; DIAS, D F and SANTOS, M H D (2014). Growth curve, biochemical profile and phytochemical analyses in calli obtained from the procambium segments of Bacupari. Braz Arch Biol Technol. Vol. 57(3): 326-333.

SEN, J; KALIA, S and GUHA-MUKHERJEE, S (2002). Level of endogenous free amino acids during various stages of culture of Vigna mungo (L.) Heppersomatics embryogenesis, organogenesis and plant regeneration. Curr. Sci. Vol. 82(4): 429-433.

SGHAIER-HAMMAMI, B; VALLEDOR, L; DRIRA, $\mathrm{N}$ and JORRIN-NOVO, J V (2009). Proteomic analysis of the development and germination of date palm (Phoenix dactylifera L.) zygotic embryos. Proteomics. Vol. 9(9): 2543-2554.

SINGLETON, V L and ROSSI, J A (1965). Colorimetry of total phenolics with phosphomolybdicphosphotungstic acid reagents. Am. J. Enol. Vitic. Vol. 16(3): 144-158.

SPURR, A R (1969). A low-viscosity epoxy resin embedding medium for electron microscopy. J. Ultrastruct Res. Vol. 26(1-2): 31-43.

STEENHOUDT, O and VANDERLEYDEN, J (2000). Azospirillum, a free-living nitrogen-fixing bacterium closely associated with grasses: Genetic, biochemical and ecological aspects. FEMS Microbiol Rev. Vol. 24(4): 487-506

TAULE, C; MAREQUE, C; BARLOCCO, C; HACKEMBRUCH, F; REIS, V M; SICARDI, $M$ and BATTISTONI, F (2012). The contribution of nitrogen fixation to sugarcane (Saccharum officinarum L.), and the identification and characterization of part of the associated diazotrophic bacterial community. Plant Soil Vol. 356(1-2): 35-49.

TE-CHATO, S and HILAE, A (2007). High-frequency plant regeneration through secondary somatic embryogenesis in oil palm (Elaeis guineensis Jacq. var. tenera). J. Agri. Tech. Vol. 3(2): 345-357.

VARGA, S S; KORANYI, P A; PREININGER, E and GYRURAN, I (1994). Artificial associations between Daucus and nitrogen-fixing Azotobacter cells in vitro. Plant Physiol. Vol. 90(4): 789-790.

VIDAL, E A and GUTIERREZ, R A (2008). A system view of nitrogen nutrient and metabolite responses in Arabidopsis. Curr. Opin. Plant Biol. Vol. 11(5): 521529.

WARCHOL, M; SKRZYPEK, E; KUSIBAB, T and DUBERT, F (2015). Induction of somatic embryogenesis and biochemical characterization of Cordyline australis (G. Forst.) Endl.'Red Star'callus. Sci. Hort. Vol. 192 (2015): 338-345. 